\title{
Survival of Coptotermes testaceus (Isoptera: Rhinotermitidae) to Environmental Conditions (Relative Humidity and Temperature) and Preference to Different Substrates
}

\author{
Co Pozo-Santiago ${ }^{1}$, M Pérez-De la Cruz ${ }^{2}$, M Torres-De la Cruz², a de la Cruz-Pérez ${ }^{2}$, S Capello-García ${ }^{2}$, \\ MA HERNÁNDEZ-GALLEGOS ${ }^{3}$, JR VELÁZQUEZ-MARTíNEZ ${ }^{4}$ \\ 1 - Facultad Maya de Estudios Agropecuarios-Universidad Autónoma de Chiapas. Catazajá, Chiapas, México \\ 2 - División Académica de Ciencias Biológicas-Universidad Juárez Autónoma de Tabasco. Villahermosa, Tabasco, México \\ 3 - División Académica Multidisciplinaria de Jalpa de Méndez-Universidad Juárez Autónoma de Tabasco. Jalpa de Méndez, Tabasco, México \\ 4 - División Académica de Ciencias Agropecuarias-Universidad Juárez Autónoma de Tabasco.Villahermosa, Tabasco, México
}

\section{Article History}

\section{Edited by}

Og DeSouza, UFV, Brazil

Thomas Chouvenc, UFL, USA

Received $\quad 10$ April 2020

Initial acceptance 29 June 2020

Final acceptance 17 August 2020

Publication date 30 September 2020

\section{Keywords}

Termite, subterranean, woods, agricultural, control, Eucalyptus urophylla.

\section{Corresponding author}

J Rodolfo Velázquez Martínez Carretera Villahermosa-Teapa, Km 25+2 Ranchería la Huasteca 2 da seccion, 86298 Villahermosa, Tabasco, México. E-Mail: jrodolfovelazquez@gmail.com

\begin{abstract}
Coptotermes testaceus (L.) (Rhinotermitidae) is a subterranean termite species that causes damage in urban and agricultural areas in the neotropics. Despite its economic importance, there are no studies on its basic biological aspects for laboratory management and the development of strategies for its control. The objective of the present study was to evaluate the relative humidity, temperature, substrate moisture and preference to different wood substrates for the best $C$. testaceus survival under laboratory conditions. For this, a range of eight relative humidity (from 9 to $100 \%$ ), three temperatures $\left(20,25\right.$ and $30{ }^{\circ} \mathrm{C}$ ), six substrates (Pinus sp, Cedrela odorata (L.), Cocos nucifera (L.), Eucalyptus urophylla (S. T. Blake), Haematoxylum campechianum (L.) and Tabebuia rosea [Bertol.] DC) and four substrate moistures, (0 to 60\%) were tested. The results of this study indicated a significant effect of all factors on termite survival or termite preference. When tested independently, the highest survival percentage of $C$. testaceus was obtained with humidity of $100 \%$, temperature of $20^{\circ} \mathrm{C}$, substrate moisture of $60 \%$ and the Eucalyptus urophylla substrate, reaching $83.33 \%$ survival at 21 days of observation. With these preliminary assays on small termite groups, it is concluded that with the appropriate percentages of humidity, temperature and substrate and the interaction of these three factors, further research can be conducted using larger termite groups in biologically relevant conditions, in order to study various aspects of $C$. testaceus biology.
\end{abstract}

\section{Introduction}

Coptotermes Wasmann (Isoptera: Rhinotermitidae), is a genus of subterranean termites that currently has 21 validated species (Chouvenc et al., 2016), of which 16 are classified as pests of economic importance in various parts of the world (Krishna et al., 2013). While only two of these species, C. formosanus Shiraki, and C. gestroi (Wasmann) have demonstrated remarkable invasive abilities, most Coptotermes species still have an economic impact in their native range. Coptotermes have the ability to infest live trees, create large, populous colonies, with extensive foraging abilities, which can reach more than $100 \mathrm{~m}$ of underground galleries (Greaves, 1962; King \& Spink, 1969; Su \& Scheffrahn, 1988). Coptotermes testaceus (L.) is the only endemic Coptotermes species in the new world and is established throughout most of the neotropics (Scheffrahn et al., 2015; Chouvenc et al., 2016). This species has been found affecting plantations of forest importance such as rubber (Hevea brasiliensis [Willd. ex A.Juss.] Müll.Arg.) (Apolinário \& Martius, 2004; Krishna et al., 2013) and eucalyptus (Eucalyptus urophylla S. T. Blake) (Santos et al., 1990; Amaral-Castro, 2004); agricultural crops 
such as cassava (Manihot esculenta C.), cocoa (Theobroma cacao L.) and sugar cane (Saccharum officinarum L.) (Krishna et al., 2013); and wooden constructions in urban areas (Bandeira et al., 1989). In Mexico, the C. testaceus population represents the northern most distribution of the species (Light, 1933; Sheffrahn et al., 2015) and was reported to have an agricultural impact, damaging roots and stems of crops of economic, social and cultural importance (López-Vera et al., 2018; Capetillo-Concepción et al., 2019).

Due to the economic importance of $C$. testaceus as a pest, it is necessary to find strategies for its control. However, to date, the environmental requirements to keep populations alive for prolonged periods of $C$. testaceus in the laboratory that allow the establishment of bioassays to evaluate their control, have not been reported. On the other hand, there is a continuous search for friendly alternatives to the environment and human health, for termite control. These studies generally start with laboratory bioassays, for example, the use of target-specific chemicals (baits and termiticides). While a lot of research efforts have been focusing on botanicals (essential oil, seed, bark, leaf, fruit, root, wood, resin) and entomopathogens (fungi, bacteria and nematodes), none has resulted in practical or commercial application (Verma et al., 2009; Chouvenc et al., 2011).

However, achieving the establishment of live subterranean termite colonies in the laboratory is logistically complicated, time consuming and challenging (Chouvenc, 2018), due to factors such as temperature (Fei \& Henderson, 2002; Nakayama et al., 2004; Gautam \& Henderson, 2011; Wiltz, 2012), humidity (Nakayama et al., 2004; Wong \& Lee, 2010; Gautam \& Henderson, 2011; Wiltz, 2012) and the food source (Smythe \& Carter, 1969; Su \& Tamashiro, 1986). Particularly, desiccation is determining factor for termite survival, so it is important that in laboratory survival studies, not only relative humidity is considered, but also the substrate moisture and food (Hu et al., 2012; Zukowski \& Su, 2017).

In order to provide preliminary information of the basic biological requirements for the survival and maintenance of C. testaceus in laboratory conditions, the aim of this study was to evaluate the survival of $C$. testaceus at various levels of relative humidity, temperature, substrate moisture, and preference for different substrates, to obtain the appropriate conditions that allow establishing live termite colonies in the laboratory, to ultimately carry out bioassays to study the control of C. testaceus.

\section{Materials and methods}

Obtaining C. testaceus

The specimens were collected in the botanical garden of the Academic Division of Biological Sciences of the Universidad Juárez Autónoma de Tabasco. Traps (modified from Tamashiro et al., 1973) built with a metal cylinder $(18.5 \mathrm{~cm}$ high $\mathrm{x} 15.5 \mathrm{~cm}$ in diameter) with exposed ends and internal walls lined with wood were used, a roll of corrugated paper $10 \mathrm{~cm}$ in diameter was placed in the center. The trap was placed in the basal part of trees that had damage caused by C. testaceus, buried in the ground $20 \mathrm{~cm}$ deep with the top of the trap covered. The corrugated paper cylinder with termites was removed after five days and transferred to the laboratory. In this study only workers were used of a single colony (a total of 1740).

\section{C. testaceus survival at different percentages of relative humidity} (RH) and temperatures

The methodology for this section was proposed by Zukowski and Su (2017), with modifications. Environmental chambers $(\mathrm{EC})$ were conditioned using plastic containers with lid $(24.7 \times 17 \times 6.4 \mathrm{~cm})$, with a $2.7 \mathrm{~cm}$ diameter hole in the central part of the lid to introduce a digital hydrometer. The $\mathrm{RH}$ inside the EC was stabilized using various stabilizing materials (RHSM) in different amounts (Table 1). To achieve a high RH, the water was placed in plastic containers $(6 \mathrm{~cm}$ diameter $\times 3.6 \mathrm{~cm}$ height) and cotton, covering the bottom of the EC; the salts and the silica gel were placed in the plastic containers described above and for the lowest $\mathrm{RH}$, the $\mathrm{CaCl}_{2}$ was spread at the bottom of the EC. The RH in the EC was assessed for 15 days with a digital hygrometer (VWR; TRACEABLE TM). The temperature was stabilized at 20, 25 and $30^{\circ} \mathrm{C}$ in an incubator (NOVATECH, MOD. DBO-200).

The bioassay was carried out using five Petri dishes in each stabilized EC, the Petri dishes $(60 \mathrm{~mm} \times 15 \mathrm{~mm})$ contained a filter paper disk $(60 \mathrm{~mm})$ to facilitate locomotion of the termites and as a source of food was pine sawdust (200 $\mathrm{mg}), 10$ termite workers were placed in each box. The daily record of live termites was monitored, reporting the survival percentage. Dead termites were removed daily. The bioassay required five repetitions with ten workers in each repetition for the eight $\mathrm{RH}$ at the three temperatures tested (a total of 1,200 workers).

Table 1. RHSM and amounts used to obtain different RH.

\begin{tabular}{llll}
\hline \multicolumn{1}{c}{ RHSM } & Formule & Amount & RH obtained $(\%)^{\mathrm{a}}$ \\
\hline Water, in cotton & $\mathrm{H}_{2} \mathrm{O}$ & $200 \mathrm{ml}$ & $100 \pm 0.25$ \\
Water & $\mathrm{H}_{2} \mathrm{O}$ & $100 \mathrm{ml}$ & $83.25 \pm 0.55$ \\
Undiluted salt & $\mathrm{Mg}\left(\mathrm{NO}_{3}\right)_{2}$ & $100 \mathrm{~g}$ & $75.28 \pm 0.77$ \\
$\begin{array}{l}\text { Saturated saline } \\
\text { solution }\end{array}$ & $\mathrm{NaCl}$ & $100 \mathrm{ml}$ & $64.88 \pm 0.59$ \\
$\begin{array}{l}\text { Silica gel } \\
\text { Saturated saline }\end{array}$ & $\mathrm{Silica} \mathrm{gel}$ & $100 \mathrm{~g}$ & $61.12 \pm 0.83$ \\
$\begin{array}{l}\text { solution } \\
\text { Undiluted salt }\end{array}$ & $\mathrm{MgCl}_{2}$ & $50 \mathrm{ml}$ & $42.98 \pm 2.43$ \\
Undiluted salt & $\mathrm{CaCl}_{2}$ & $100 \mathrm{~g}$ & $23.88 \pm 1.55$ \\
\hline
\end{tabular}

${ }^{\mathrm{a}}$ Mean $(\mathrm{M}) \pm$ Standard Error (SE). $\mathrm{n}=18$. 
C. testaceus preference towards different substrates (woods)

Sawdust from pine (Pinus sp.), cedar (Cedrela odorata L.), coconut fiber (Cocos nucifera L.), eucalyptus (Eucalyptus urophylla S. T. Blake), blackwood (Haematoxylum campechianum L.) and pink poui (Tabebuia rosea [ Bertol.] DC) were used with a homogeneous particle size (sieve No. 16, $1.13 \mathrm{~mm}$ spacing). They were dehydrated in a drying oven (Felisa ${ }^{\circledR}$ Brand) at $50{ }^{\circ} \mathrm{C}$ for $24 \mathrm{~h}$ and stored in a desiccator with dehydrator until use for bioassays.

A device was designed to allow a high $\mathrm{RH}$ and for termites to choose between different substrates (Fig 1). Small environmental chambers (sEC) were used, which consisted of $8 \times 5.5 \mathrm{~cm}$ (diameter $\times$ height) circular plastic containers, which inside contained plastic vials of $4 \times 2 \mathrm{~cm}$, suspended inside each sEC. Cotton was placed at the bottom of each radial sEC with water to obtain the RH of $100 \%$ and the substrates were placed in the vials (Fig 1a). Using $6 \times 1 \mathrm{~cm}$ plastic tubes, six radial $\mathrm{sEC}$ were connected to a central chamber. The device was placed in the incubator at $20^{\circ} \mathrm{C}$ and the $\mathrm{RH}$ and temperature were stabilized for $4 \mathrm{~h}$. Once the $\mathrm{RH}$ and temperature had stabilized, 30 termites were deposited in the central chamber and at $24 \mathrm{~h}$ the number of termites within each sEC with substrate was recorded, the termites found in the connection tubes were also included in the counts. The aggregation of termites to substrates was considered as preference. The RH and temperature were monitored during the bioassay and the percentage of preference was reported. The bioassay required ten repetitions with 30 workers in each repetition (a total of 300 workers).

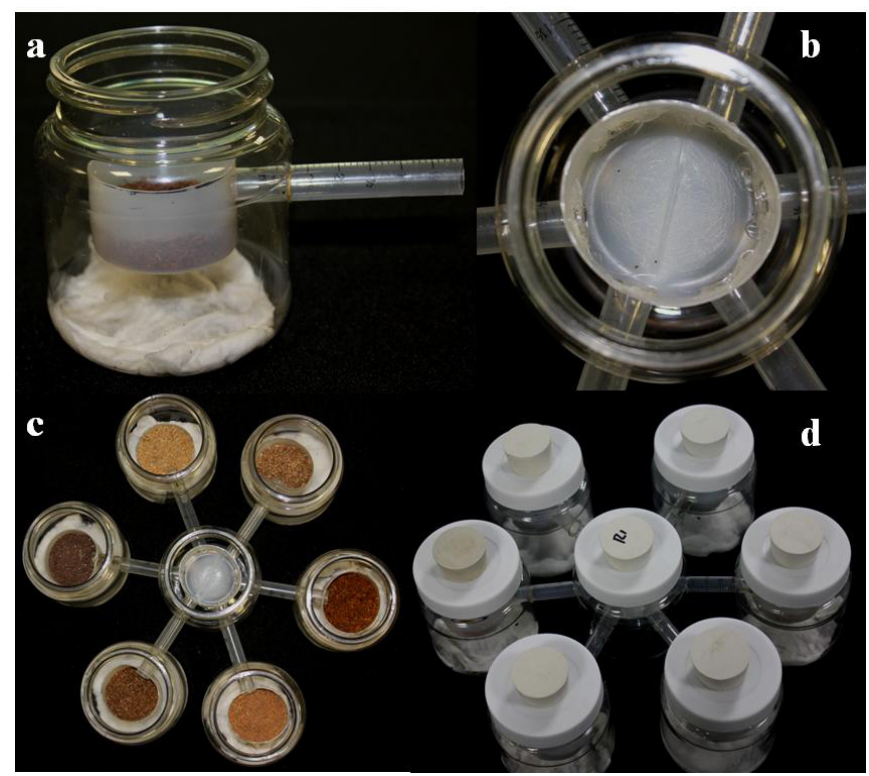

Fig 1. Device for high $\mathrm{RH}$ and preference of termites towards different substrates. a) Radial small environmental chamber, with suspended vial; b) Central chamber for release of termites with vial connected to six radial small environmental chambers; c) device with the six substrates for multiple choice; d) device with modified caps for HR monitoring.
Survival of C. testaceus at different substrate moisture

The most preferred substrate previously conditioned was used. In Petri dishes $(60 \mathrm{~mm} \times 15 \mathrm{~mm}) 3 \mathrm{~g}$ of the substrate were placed and sterile distilled water was used to obtain substrate moistures $(\mathrm{SH})$ of $0,20,40$ and $60 \%$.The formula used to obtain the desired SH (NMX-AA-16-1984) was as follows: $H=\underline{G-G 1} \times 100$

$G$

Where: $\mathrm{H}=\%$ of humidity

$\mathbf{G}=$ Wet sample weight in $\mathrm{g}$

$\mathrm{G} 1=$ Dry sample weight in $\mathrm{g}$

Six Petri dishes were placed in environmental chambers (used in the survival test at different $\mathrm{RH}$ and temperature) with the stabilized RH of $100 \pm 0.25 \%$ (Fig 2a). Groups of ten termites were placed in each Petri dish with the substrate at the required humidity (Fig 2b). This bioassay was incubated at $20^{\circ} \mathrm{C}$ in total darkness. The daily count of living termites was recorded, and the survival (percentage of live termites) was reported. The bioassay required six repetitions with ten workers in each repetition for the four SH evaluated (in total 240 workers).

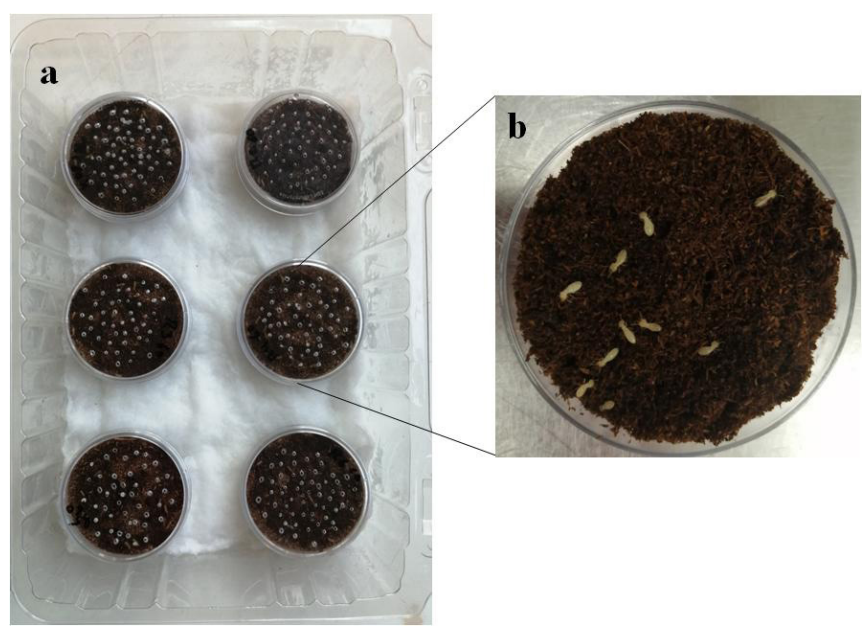

Fig 2. a) Petri dishes in environmental chambers with the stabilized $\mathrm{RH}$ of $100 \pm 0.25 \%$; b) Group of ten termites placed in the Petri dish with the substrate at the required humidity.

\section{Experimental design and statistical analysis}

For all bioassays, a completely randomized simple design was used. The statistical analysis used for the termite survival test at different RHs and temperatures was an analysis of variance (ANOVA) for an 8 by 3 factorial experimental design ( $8 \mathrm{RHs}$ and 3 temperatures), the response variable was the percentage of survival. Statistical analysis for preference towards different substrates was performed with a simple analysis of variance (ANOVA) and the percentage of preference as the response variable. A comparison of means with Fisher's LSD with an $\alpha=0.05$ was performed for these two trials. Finally, for the survival of termites towards different SH, a Kaplan-Meier LogRank analysis and the comparison of Holm Sidak means with an $\alpha=0.05$ were used, where the 
highest median lethal time $\left(\mathrm{LT}_{50}\right)$ was considered to select the best treatment. Because the results of the first two trials were expressed as a percentage, it was necessary to transform the data to the square root of the arcsine prior to ANOVA. The statistical package used for all analyzes was SigmaPlot 12.0.

\section{Results}

\section{C. testaceus survival at various $R H$ levels and temperatures}

Table 2 shows the survival rate of $C$. testaceus 24 hours after being exposed to eight $\mathrm{RH}$ and three temperatures. The $\mathrm{RH}$ of $100 \%$ presents the highest percentage of survival at 24 hours of observation for the three temperatures evaluated $(\mathrm{F}=$ $109,313$; df $=7$; $\mathrm{P}<0.001)$. There was a greater survival of termites at a temperature of $20^{\circ} \mathrm{C}(\mathrm{F}=192,213 ; \mathrm{df}=2 ; \mathrm{P}<0.001)$. On the other hand, the interaction between the two studied factors, in the same way, generated a significant effect $(\mathrm{F}=$ 7,$885 ; \mathrm{df}=14 ; \mathrm{p}<0.001$ ), being the combination of $20^{\circ} \mathrm{C}$ and $100 \% \mathrm{RH}$ the treatment that provided the highest termite survival, with $88.4 \pm 0.07 \%$. Likewise, it was observed that as the RH decreases, the termite survival also does it gradually, while at higher temperatures, it's a lower survival.

\section{C. testaceus preference for various substrates (woods)}

Termites showed a statistically different response in their aggregation toward a substrate after 24 hours of observation ( $\mathrm{F}=4,630 ; \mathrm{df}=5 ; \mathrm{p}<0.001$, Fisher's LSD $\alpha=0.05)$. The most preferentially aggregated on eucalyptus, with $68.75 \%$, followed by blackwood with $12.5 \%$ and pine with $10 \%$. The substrates that obtained the lowest preferences were coconut fiber, pink poui and cedar, with $4.38,4.37$ and $0.0 \%$ respectively (Fig 3).

Survival of C. testaceus at different substrate moisture (SH)

The four SHs showed a significant difference (Statistic $=385,312 ; \mathrm{df}=3 ; \mathrm{P}<0.001)$ with respect to $C$. testaceus survival during the bioassay. The $\mathrm{SH}$ of $60 \%$ obtained the highest survival, $\mathrm{a} \mathrm{TT}_{50}$ value was not recorded, because after 21 days of the bioassay the percentage of live termites was $83 \%\left(\mathrm{LT}_{50}>21\right.$ days $)$. The $\mathrm{SH}$ of $40 \%, 20 \%$ and $0 \%$ obtained a $\mathrm{LT}_{50}$ of 21, 13 and 1 days, respectively (Fig 4).

Table 2. Percentage of survival $(\mathrm{M} \pm \mathrm{SE})$ of Coptotermes testaceus 24 hours after being exposed to eight RHs and three temperatures. $\mathrm{n}=5$.

\begin{tabular}{ccccccccc}
\hline & \multicolumn{7}{c}{$\mathrm{RH}^{\mathrm{a}}$} \\
\cline { 2 - 8 } & $\mathrm{H}_{2} \mathrm{O}$ & $\mathrm{H}_{2} \mathrm{O}$ & $\mathrm{Mg}\left(\mathrm{NO}_{3}\right)_{2}$ & $\mathrm{NaCl}$ & Síl GEL & $\mathrm{MgCl}_{2}$ & $\mathrm{CaCl}_{2}$ & $\mathrm{CaCl}_{2}$ \\
$\mathrm{~T}^{\circ} \mathrm{C}$ & $(100 \pm 0.3 \%)$ & $(83.25 \pm 0.5 \%)$ & $(75.28 \pm 0.8 \%)$ & $(64.88 \pm 2.5 \%)$ & $(61.12 \pm 3.5 \%)$ & $(42.98 \pm 2.4 \%)$ & $(23.88 \pm 0.4 \%)$ & $(9.89 \pm 0.1 \%)$ \\
\hline 20 & $88.4 \pm 0.07 \mathrm{Aa}$ & $71.8 \pm 0.07 \mathrm{Ab}$ & $70.5 \pm 0.07 \mathrm{Ab}$ & $69.8 \pm 0.07 \mathrm{Ab}$ & $39.6 \pm 0.07 \mathrm{Ac}$ & $31.5 \pm 0.07 \mathrm{Acd}$ & $31.5 \pm 0.07 \mathrm{Acd}$ & $20.7 \pm 0.07 \mathrm{Ad}$ \\
25 & $74.7 \pm 0.06 \mathrm{Ba}$ & $59.5 \pm 0.06 \mathrm{Ab}$ & $9.3 \pm 0.06 \mathrm{Bc}$ & $9.3 \pm 0.06 \mathrm{Bc}$ & $6.7 \pm 0.06 \mathrm{Bc}$ & $0.0 \pm 0.0 \mathrm{Bc}$ & $0.0 \pm 0.0 \mathrm{Bc}$ & $0.0 \pm 0.0 \mathrm{Bc}$ \\
30 & $74.7 \pm 0.05 \mathrm{Ba}$ & $23.2 \pm 0.05 \mathrm{Bb}$ & $13.9 \pm 0.06 \mathrm{Bbc}$ & $9.26 \pm 0.05 \mathrm{Bcd}$ & $4.63 \pm 0.05 \mathrm{Bcd}$ & $0.0 \pm 0.0 \mathrm{Bd}$ & $0.0 \pm 0.0 \mathrm{Bd}$ & $0.0 \pm 0.0 \mathrm{Bd}$ \\
\hline
\end{tabular}

${ }^{a}$ Different lowercase letters within a row or different uppercase letters within a column indicate significant differences between Means.

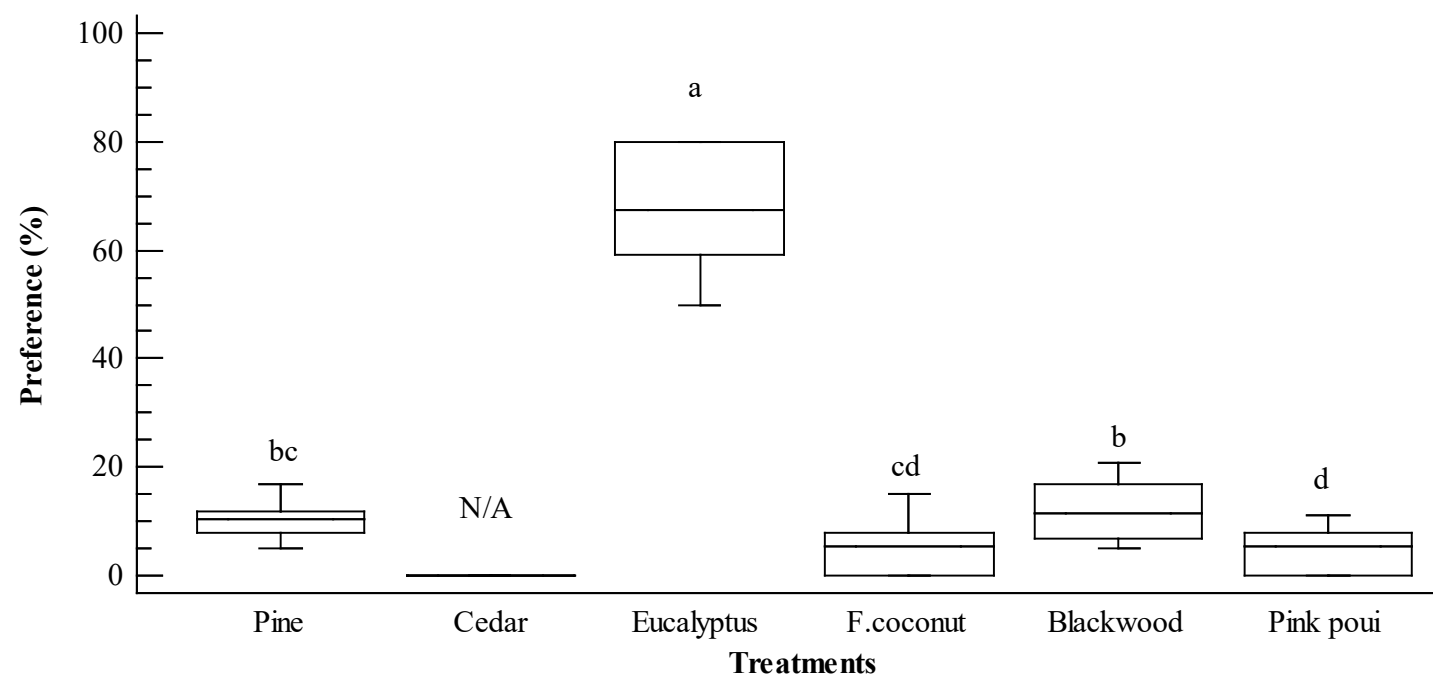

Fig 3. Percentage of preference of Coptotermes testaceus workers 24 hours after being exposed to six substrates (woods), at an $\mathrm{RH}$ of $100 \%$ and a temperature of $20^{\circ} \mathrm{C}, \mathrm{n}=10$. Different letters indicate significant differences between treatments. 


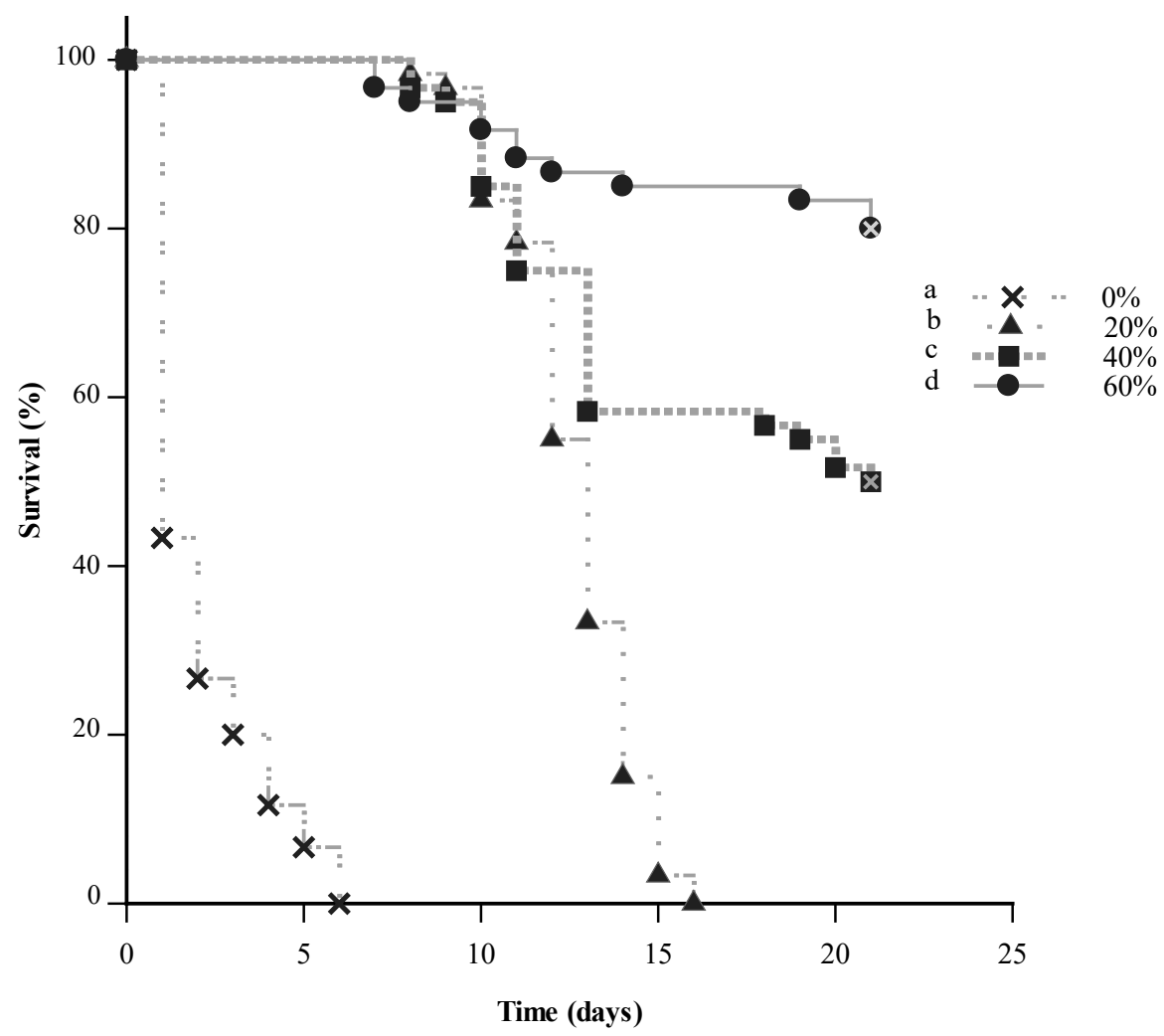

Fig 4. Percentage of survival of Coptotermes testaceus workers after being exposed to four substrate moistures $(0 \%, 20 \%, 40 \%$ and $60 \%)$ at $20{ }^{\circ} \mathrm{C}$ and $100 \% \mathrm{RH}, \mathrm{n}=6$. Different letters on substrate moisture indicate significant differences (Holm Sidak, $\alpha=0.05$ ).

\section{Discussion}

The results of this study showed that the highest survival $(88.4 \%)$ of C. testaceus was at $100 \% \mathrm{RH}$ and temperature of $20{ }^{\circ} \mathrm{C}$. This shows that both $\mathrm{RH}$ and temperature are important for the survival of $C$. testaceus, but they are even more so when the interaction between these factors occurs. This agrees with that reported by Gautam and Henderson (2011) as well as Wiltz (2012), who found the highest survival percentages for C. formosanus at low temperatures $\left(20\right.$ and $\left.10^{\circ} \mathrm{C}\right)$ and high RH (98 and 99\%) respectively. The results of this study show an effect of RH and temperature, however, these two factors alone cannot maintain the in vitro survival for long periods of time ( $24 \mathrm{~h}$ for this study), which is necessary for studies focusing on control aspects of this pest.

Lenz (2005) points to substrate as another factor that must be considered to obtain successful results in bioassays. The substrate can be used for the construction of their galleries, food or as indicated by $\mathrm{Hu}$ et al. (2012) and Zukowski and $\mathrm{Su}$ (2017), a resource for obtaining moisture. That is why, in this study, the preference that $C$. testaceus had towards six different woods that could function as a substrate was also evaluated. The results obtained in this work indicated that eucalyptus was the substrate with the greatest choice. This coincides with studies carried out in agricultural systems where it was reported that $C$. testaceus was the main responsible for infestations in eucalyptus plantations (Amaral et al., 2004). This could be due to the fact that, as Zabel and Morrel (1992) points out, the different kinds of wood have the presence of extractable (chemicals). The part of the wood in which the extractables are produced is what determines if they play a role as attractants or repellents, i.e. in the sapwood, there is a higher concentration of starch and carbohydrates which makes this part of the wood more palatable to the biological agents that attack it. On the other hand, the heartwood has a series of components that make it less preferred to these agents (Kollmann, 1959). This leads us to think that eucalyptus was the most attractive substrate due to its chemical composition, in addition to cellulose, which is the main food source of xylophagous insects, such as termites (Bignell \& Eggleton, 2000; Ramírez \& Lanfranco, 2001; Shimada \& Maekawa, 2010). This coincides with that reported by Scheffrahn (1991), who likewise attributes the preference of termites to this type of (extractable) substances.

Finally, and once the most preferred substrate was identified, different humidity levels were evaluated in this substrate. McManamy et al. (2008) pointed out that the humidity of the substrate is an important factor for the prolonged survival of species of subterranean termites, this due to the fact that after subjecting Reticulitermes flavipes (Kollar) (Isoptera: Rhinotermitidae) to ideal conditions of temperature and $\mathrm{RH}$, but exposed to low moisture wood, 
the termites did not survive. Our results indicated that the humidity of the substrate of $60 \%$ (the highest tested), was the one with which the longest survival time of the termite (21 days) was reached, reaching $83.33 \%$ of live insects at the end of this time. This coincides with that reported by Zukowski and $\mathrm{Su}$ (2017) for the termite species C. formosanus, which, after three weeks of observation (21 days), reached $90 \%$ survival with wet food, but when the food source provided was dry, survival was $0 \%$. These results lead us to agree with what was pointed out by Gautam and Henderson (2014), who pointed out that subterranean termite species are extremely susceptible to desiccation, therefore, they require not only high $\mathrm{RH}$, but also other sources of humidity for its greatest survival.

At a global level, although studies of this type were conducted on pest species of subterranean termites (Rhinotermitidae), the current study provides preliminary information on optimal experimental and rearing conditions in the laboratory for C. testaceus. As previously shown, the importance of the biological relevancy of a bioassay when testing control method against subterranean termites in laboratory conditions is critical ( $\mathrm{Su}, 2005$; Chouvenc, 2018), to study the applicability of such approach in a field situation. The current study therefore provides initial guidelines for the manipulation of $C$. testaceus in the laboratory, thus being able to carry out future studies aimed at testing control approach for this species.

\section{Acknowledgments}

Cordial thanks to the editor and referees for their reviews and comments on our manuscript. To the Universidad Juárez Autónoma de Tabasco, for facilitating access to the laboratories, materials, and equipment of the Academic Division of Biological Sciences (DacBiol), the Academic Division of Agricultural Sciences (DACA), the Academic Division of Multidisciplinary of Jalpa de Mendez (DAMJM).To the National Council of Science and Technology (CONACYT) of Mexico for the scholarship awarded to carry out this study.

\section{Contribution of the authors}

CO Pozo-Santiago, conception, design, data collection, analysis, interpretation of results and document writing; $\mathrm{M}$ Pérez-De la Cruz, conception, design, critical review for important intellectual content, interpretation of results and final approval of the version to be published; JR VelázquezMartínez, conception, design, critical review for important intellectual content, interpretation of results and final approval of the version to be published; M Torres-De la Cruz, design, critical review for important intellectual content, interpretation of results and final approval of the version to be published; A De la Cruz-Pérez, design, critical review for important intellectual content, and final approval of the version to be published; S Capello-García, design, critical review for important intellectual content, and final approval of the version to be published; MA Hernández-Gallegos, critical review for important intellectual content, and final approval of the version to be published.

\section{References}

Amaral-Castro, N.R., Zanetti, R., Moraes, J.C., Zanuncio, J.C., Freitas, G.D. \& Santos, M.S. (2004). Species of soil inhabiting termites (Insecta: Isoptera) collected in Eucalyptus plantations in the state of Minas Gerais, Brazil. Sociobiology, 44: 717-726.

Apolinário, F.E., \& Martius, C. (2004). Ecological role of termites (Insecta, Isoptera) in tree trunks in central Amazonian rain forests. Forest Ecology and Management, 194: 23-28. doi: 10.1016/j.foreco.2004.01.052.

Bandeira, A. G., Gomes, I., Lisboa, B., Souza, S. (1989). Insetos pragas de madeiras de edificações em Belém-Pará. Embrapa Amazônia. Oriental-Séries anteriores (INFOTECA-E).

Bignell, DE \& Eggleton, P. (2000). Termites in ecosystems. In T Abe, DE BignellyM Higashi (Eds), Termites: Evolution, sociality, symbioses, ecology (pp. 363-388). Dordrecht: Kluwer Academic Publishers.

Capetillo-Concepción, E., Pérez-De La Cruz, M., De La CruzPérez, A. and Magaña-Alejandro, M.A. (2019). Hospederos, infestación y distribución de Coptotermes testaceus (Linnaeus) (Blattodea: Rhinotermitidae) en areas forestales de Tabasco, México. Revista Chilena de Entomología, 45: 533-543. doi: 10.35249/rche.45.4.19.04.

Chouvenc, T. (2018). Comparative impact of chitin synthesis inhibitor baits and non-repellent liquid termiticides on subterranean termite colonies over foraging distances: colony elimination versus localized termite exclusion. Journal of Economic Entomology, 111: 2317-2328. doi: 10.1093/jee/ toy 210 .

Chouvenc, T., Li, H. F., Austin, J., Bordereau, C., Bourguignon, T., Cameron, S. L. et al. (2016). Revisiting Coptotermes (Isoptera: Rhinotermitidae): a global taxonomic road map for species validity and distribution of an economically important subterranean termite genus. Systematic Entomology, 41: 299306. doi: 10.1111/syen.12157.

Chouvenc, T., Su, N.Y. \& Grace, J.K. (2011). Fifty years of attempted biological control of termites-Analysis of a failure. Biological Control, 59: 69-82. doi: 10.1016/j. biocontrol.2011.06.015.

Fei, H. \& Henderson, G. (2002) Formosan subterranean termite (Isoptera: Rhinotermitidae) wood consumption and worker survival as affected by temperature and soldier proportion. Environmental Entomology, 31: 509-514. doi: 10.1603/0046-225X-31.3.509.

Gautam, B.K. \& Henderson, G. (2014). Water transport by Coptotermes formosanus (Isoptera: Rhinotermitidae). Environmental Entomology, 43: 1399-1405. 
Gautam, B. K. \& Henderson, G. (2011). Wood consumption by Formosan subterranean termites (Isoptera: Rhinotermitidae) as affected by wood moisture content and temperature. Annals of the Entomological Society of America, 104: 459-464. doi: 10.1603/AN10190.

Greaves, T., 1962. Studies of foraging galleries and the invasión of living tres by Coptotermes acinaciformis and $C$. brunneus (Isoptera). Australian Journal of Zoology, 10: 630651.

Hu, J., Neoh, K.B., Appel, A.G. \& Lee, C.Y. (2012). Subterranean termite open-air foraging and tolerance to desiccation: Comparative water relation of two sympatric Macrotermes spp. (Blattodea: Termitidae). Comparative Biochemistry and Physiology Part A: Molecular \& Integrative Physiology, 161: 201-207. doi: 10.1016/j.cbpa.2011.10.028.

King Jr, E.G. and Spink, W.T. (1969). Foraging galleries of the Formosan subterranean termite, Coptotermes formosanus, in Louisiana. Annals of the Entomological Society of America, 62: 536-542.

Kollmann, F. (1959). Tecnología de la madera y sus aplicaciones. Ministerio de Agricultura, Madrid, España. 675 p.

Krishna, K., Grimaldi, D.A., Krishna, V. \& Engel, M.S. (2013). Treatise on the Isoptera of the World: Vol.1. Bulletin of the American Museum of Natural History, 377: 1-200. doi: 10.1206/377.7.

Lenz, M (2005). Laboratory bioassays with termites-the importance of termite biology. In $\mathrm{K}$ Tsunoda (Eds.), Proceeding the $2^{\mathrm{a}}$ conference of pacific rim termite research group on wood protection (pp. 53-60). Bangkok, Thailand.

Light S.F. (1933). Termites of western Mexico. - University of California Publications in Entomology, 6: 79-152 + plates

López-Vera, E.E., Hernández-Pérez, L., López-Corzo, A., Sámano-Garduño, D. \& Domínguez-Monge, S. (2018). Primer Registro de Coptotermes testaceus Afectando Maíz (Zea mays L.) en el Estado de Campeche, México. Southwestern Entomologist, 43: 811-814.doi: 10.3958/059.043.0330.

McManamy, K., Koehler, P.G., Branscome, D.D. \& Pereira, R.M. (2008). Wood moisture content affects the survival of eastern subterranean termites (Isoptera: Rhinotermitidae), under saturated relative humidity conditions. Sociobiology, 52: 145-156.

Nakayama, T., Yoshimura, T. \& Imamura, Y. (2004). The optimum temperature-humidity combination for the feeding activities of Japanese subterranean termites. Journal of Wood Science, 50: 530-534. doi: 10.1007/s10086-003-0594-y.

Norma Mexicana NMX-AA-16-1984. Protección al ambientecontaminación del suelo-residuos solidos municipalesdeterminación de humedad. URL:http://legismex.mty.itesm. $\mathrm{mx} /$ normas/aa/aa016.pdf

Ramírez, C. \& Lanfranco, D. (2001). Descripción de la biología, daño y control de las termitas: especies existentes en Chile. Bosque, 22: 77-84. doi: 10.4206/bosque.2001.v22n2-08.

Santos, G. P., Zanuncio, J. C., Anjos, N. D., \& Zanuncio, T. V. (1990). Danos em pavoamentos de Eucalyptus grandis pelo cupim de cerne Coptotermes testaceus Linnée, 1985 (Isoptera: Rhinotermitidae). Revista Arvore, 14: 155-163.

Scheffrahn, R. H. (1991). Allelochemical resistance of woods to termites. Sociobiology, 19: 257-281.

Scheffrahn, R.H., Carrijo, T.F., Křeček, J., Su, N.Y., Szalanski, A.L., Austin, J.W., Chase, J.A. and Mangold, J.R., 2015. A single endemic and three exotic species of the termite genus Coptotermes (Isoptera, Rhinotermitidae) in the New World. Arthropod Systematics and Phylogeny, 73: 333-348.

Shimada, K., \& Maekawa, K. (2010). Changes in endogenous cellulase gene expression levels and reproductive characteristics of primary and secondary reproductives with colony development of the termite Reticulitermes speratus (Isoptera: Rhinotermitidae). Journal of Insect Physiology, 56: 11181124. doi: 10.1016/j.jinsphys.2010.03.011.

Smythe, R.V. \& Carter, F.L. (1969). Feeding responses to sound wood by the eastern subterranean termite Reticulitermes flavipes. Annals of the Entomological Society of America, 62: 335-337. doi: 10.1093/aesa/62.2.335.

Su, N.Y. \& Scheffrahn, R.H. (1988). Foraging population and territory of the Formosan subterranean termite (Isoptera: Rhinotermitidae) in an urban environment. Sociobiology, 14: 353-360.

Su, N.Y. \& Tamashiro, M. (1986). Wood-consumption rate and survival of the Formosan subterranean termite (Isoptera: Rhinotermitidae) when fed one of six woods used commercially in Hawaii. Hawaiian Entomological Society, 26, 109-113.

Su, N.Y. (2005). Response of the Formosan subterranean termites (Isoptera: Rhinotermitidae) to baits or non repellent termiticides in extended foraging arenas. Journal of Economic Entomology, 98: 2143-2152.

Tamashiro, M., Fujii, J.K. \& Lai, P.Y. (1973). A simple method to observe, trap, and prepare large numbers of subterranean termites for laboratory and field experiments. Environmental Entomology, 2: 721-722. doi: 10.1093/ee/2.4.721

Verma, M., Sharma, S. \& Prasad, R. (2009). Biological alternatives for termite control: a review. International Biodeterioration and Biodegradation, 63: 959-972. doi: 10.10 16/j.ibiod.2009.05.009.

Wiltz, B. (2012). Effect of temperature and humidity on survival of Coptotermes formosanus and Reticulitermes flavipes (Isoptera: Rhinotermitidae). Sociobiology, 59: 381394. doi: 10.13102/sociobiology.v59i2.883.

Wong, N. \& Lee, C.Y. (2010). Effects of disturbance and the presence of termite and other invertebrate carcasses 
at feeding sites on the behavior of the subterranean termite Microcerotermes crassus (Blattodea: Termitidae). Sociobiology, 55: 353-368. URL: http://www.chowyang. com/uploads/2/4/3/5/24359966/119.pdf.

Zabel, R.A. \& Morrell, J.J. (1992). Wood Microbiology:

Decay and Its Prevention. Academic Press, London, 467 p.
Zukowski, J. \& Su, N.Y. (2017). Survival of termites (Isoptera) exposed to various levels of relative humidity $(\mathrm{RH})$ and water availability, and their RH preferences. Florida Entomologist, 100: 532-539. doi: 10.1653/024.100.0307.

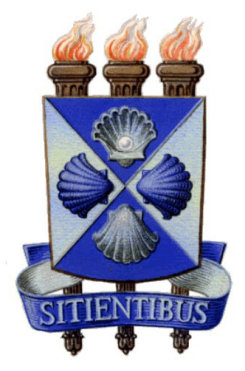

